\title{
Residues Decomposition in Crop Rotations under No-till System
}

\author{
Lutécia Beatriz dos Santos Canalli ${ }^{*}$ \\ https://orcid.org/0000-0003-0821-8584 \\ Josiane Bürkner dos Santos ${ }^{1}$ \\ https://orcid.org/0000-0003-1252-869X \\ Andressa Andrade e Silva ${ }^{1}$ \\ https://orcid.org/0000-0003-0135-4065
}

\author{
Angela Muchinski ${ }^{2}$ \\ https://orcid.org/0000-0002-0336-9300 \\ Emillyn Feliciano ${ }^{2}$ \\ https://orcid.org/0000-0003-1001-9568 \\ Daiane Penteado ${ }^{2}$ \\ https://orcid.org/0000-0001-7124-2742
}

${ }^{1}$ Paraná Agronomic Institute (IAPAR), Ponta Grossa, Paraná, Brazil; ${ }^{2}$ Centro de Ensino Superior dos Campos Gerais (CESCAGE), Agronomy/Scientific Initiation Program of IAPAR, Ponta Grossa, Paraná, Brazil.

Received: 2019.09.29; Accepted: 2020.04.09.

*Correspondence: e-mail: lutecia@iapar.br; Tel.: +55 (42) 3219-9712.

\section{HIGHLIGHTS}

- Poaceae present high $\mathrm{C} / \mathrm{N}$ ratio, decomposing gradually, protecting soil for more time.

- Fabaceae present low $\mathrm{C} / \mathrm{N}$ ratio, biological $\mathrm{N}$ fixation, supplying $\mathrm{N}$ for crops follow.

- Poacea and Fabacea consortium bring diversification, N supply and soil protection.

\begin{abstract}
The effectiveness soil cover in no-till is relating to quantity and quality of the phytomass produced by crops in rotation and, its persistence over the soil depends on residues decomposition. The objective of this study was to evaluate the phytomass production, decomposition rate and the half-life of crops in rotation at the Subtropical region, Brazil. The study was carried out at the Agronomic Institute of the Paraná (IAPAR), in Ponta Grossa, Parana State, Brazil. The experimental design was randomized blocks, with six treatments and four replicates. Winter cash crops and cover crops, single and in consortium, were evaluated in the year 2014 (wheat, black oats + hairy vetch + rye, black oats + ryegrass and black oats + blue lupine), in 2015 (canola, black oats, and black oats + hairy vetch + forage turnip) and in 2016 (barley, triticale, and triticale + black oats + rye). The phytomass was evaluating by collect three subsamples of $0.25 \mathrm{~m}^{2}$ per plot. For decomposition rate and the half-life of the crop residues, litter bags (LBs) methodology was used. A mathematical model $\left(Q=Q_{0} \exp ^{-k t}\right)$ was used to represent the crop residues decomposition and the half-life of crop residues were obtained by the equation $t_{1 / 2}=(\ln 2) / k$. Poaceae consortia, single Poaceae and canola presented higher phytomass production when compared to Poaceae-Fabaceae consortia. The half-life for Poaceae-Fabaceae corsortia was shorter than single Poaceae.
\end{abstract}

Keywords: Cover crops; decomposition rate; phytomass production; residues half-life. 


\section{INTRODUCTION}

One of the premises of the no-till system (NTS) is the maintenance of soil cover, which is related to the quantity and quality of biomass produced by crops. Crops rotation, including cover crops, is an important strategy for effective soil cover. The decomposition of crop residues depends on biotic and abiotic factors, plants composition and climate conditions and determines the residence time of the residues on the soil.

Crop rotation is the arrangement of different plant species, following a pre-established sequence, in the same area over the time, presenting the chosen species, economic purposes and or improvement of the agricultural system [1]. It stands out mainly by the improvement in the soil chemical, physical and biological attributes; protection against erosion; increases infiltration rate and water retention in the soil; improves weed, diseases and pests control; promotes nutrient cycling and biological nitrogen fixation [2,3].

It is also important to know the decomposition process and nutrients release from such plant residues and, should be chosen plants that have compatible cycles [4,5], to not compromising the development of cash crops.

The inclusion of cover crops in crops rotation enables greater efficiency in soil cover formation in NTS. Cover crops can be sown single or in consortium, and the consortium can be between species of the same or different genera [6]. The advantages of using consortia are the synergistic effects, such as soil attributes improvement and crop residues with intermediary $\mathrm{C} / \mathrm{N}$ ratio, promoting a positive balance and accumulation of $\mathrm{C}$ over the years. In the case of Fabaceae insertion in the consortia, the advantages can be evidenced by increase of nitrogen $(\mathrm{N})$ in the soil, due to its ability of biological fixation of atmospheric nitrogen through specialized bacteria. Superior results in the production of green corn after winter cover crops were observed when compared to the spontaneously vegetated plots, showing an increase of $4000 \mathrm{~kg} \mathrm{ha}^{-1}$ in ears [7]. This is due to cover crops have the ability to promote nutrient cycling and $\mathrm{N}$ fixation in the soil.

Decomposition is a process of transformation of the crop residues through the action of heterotrophic soil microorganisms, which process less stable compounds until they reach high degree of stability or humification. The speed which the crop residues decomposes determines the time of their residence on the soil and the release of nutrients present of their tissues [8]. Decomposition may range among materials, especially due to the chemical composition of the materials $(\mathrm{C} / \mathrm{N}$ ratio, cellulose, lignin and hemicellulose content), the quality and quantity of decomposing macro and microorganisms, and the edaphoclimatic conditions, mainly the temperature and rainfall $[9,10]$.

It is known that the $\mathrm{C} / \mathrm{N}$ ratio of crop residues is one of the main factors, if not the main, in defining the time required for the decomposition of residues. Due to the low $\mathrm{C} / \mathrm{N}$ ratio of Fabaceae crops (below 20), the decomposition of these materials is faster, leaving the soil unprotected early in the development of the successor crop, but nutrients are quickly released, becoming available to the successor crop, mainly nitrogen [11]. On the other hand, Poaceae with high $\mathrm{C} / \mathrm{N}$ ratio (above 25 ) remain on the soil surface for a longer period, protecting it, but have no immediate nutrients release, which happens along the time. Non-Poacea species such as vetch and forage turnip have lower $\mathrm{C} / \mathrm{N}$ ratio and, consequently, higher decomposition rate [12].

An alternative to obtain crop residues with intermediate $\mathrm{C} / \mathrm{N}$ ratio (between 20 and 25) is the use of Poaceae-Fabaceae consortium. Poaceae with Fabaceae results in materials with intermediate $\mathrm{C} / \mathrm{N}$ ratio, benefiting the soil with vegetal cover for a longer period, associated with nutrient supply according to the demand of the successive crops [13]. In the evaluation of the potential of cover crops in soil protection, was reported that the consortium between oats + vetch + turnip showed an intermediate decomposition compared to single crops, remaining $1.045 \mathrm{~kg} \mathrm{ha}^{-1}$ of residues on the soil surface 120 days after cover crops management [14]. The authors found that the consortium between oats + vetches and oats + vetches + turnip had remaining dry mass of $41 \%$ in relation to the initial one, with results similar to oats $(43 \%)$, however, the consortium is different of single oats by adding $\mathrm{N}$ to the soil, which is a beneficial feature for chemical quality of the soil.

Studies about decomposition and nitrogen $(\mathrm{N})$ release from crop residues, cultivated single or in consortium, show that Fabaceae, especially in single crop, have an accelerated decomposition after management, even in NTS, causing mismatch between $\mathrm{N}$ release and $\mathrm{N}$ demand by crops in succession. The high decomposition rate of Fabaceae, resulting from the low $\mathrm{C} / \mathrm{N}$ ratio of its residues, also contributes to reducing its efficiency in maintaining moisture and protecting soil against erosion [15].

The objective of this study was to evaluate the phytomass production, the decomposition rate and the half-life of winter species, single or in consortium in crop rotation systems under no-till, in order to support farmers for decision making when establishing appropriate crop rotations in the Southern Center region of Paraná, Brazil. 


\section{MATERIAL AND METHODS}

The experiment was carried out at the Experimental Station of the Paraná Agronomic Institute (IAPAR), in Ponta Grossa, Paraná state, Brazil, geographically located at 250.7'32"S latitude and 500.'37"W longitude, with an approximate altitude of $922 \mathrm{~m}$ at sea level.

The soil at the experiment site is classified as typical dystrophic Oxisol (Rhodic Hapludox), with 14\% loam, $28 \%$ clay, $58 \%$ sandy texture, moderate A horizon [16], with slope of $7 \%$.

The climate of the region, according to Köppen's classification is $\mathrm{Cfb}$, humid subtropical mesothermic, with fresh summers and the frosts are frequent in winter [17], with an average annual temperature of $18^{\circ} \mathrm{C}$ and average annual precipitation of $1550 \mathrm{~mm}$ [18], without the presence of a defined dry season. Figure 1 shows the average monthly weather data of temperature and precipitation during the period of the present study.
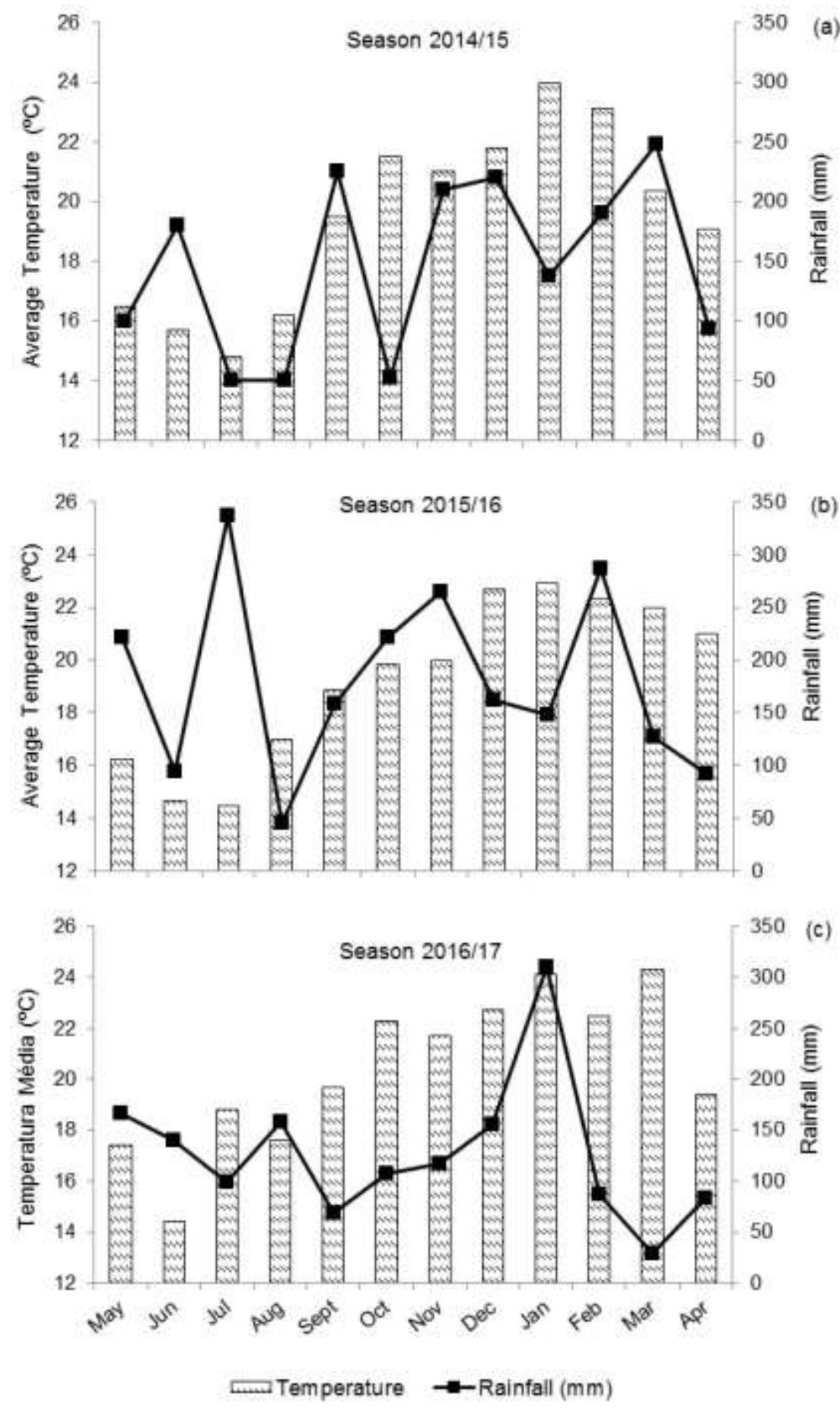

Figure 1. Annual distribution of rainfall and average temperature for the evaluation period of the present study, in 2014/15 (a), 2015/16 (b) and 2016/2017 (c) seasons.

Source: IAPAR, Ponta Grossa Metheorologycal Station. 
The experiment was implemented in April 2014 in an area that had been managed under no-till system for four years, where in winter black oat was sown for grazing animals and in summer, alternately,was cultivated corn and soybeans.

The experimental design was a randomized blocks design with six treatments and four replications. The plots dimension was $10 \times 30$ meters.

The treatments consisted of one crops succession and five crop rotations, under no-till system, in a threeyear cycle as shown in Table 1. The arrangement of the crops in each treatment was:1) Succession (Crops succession) - consisted of wheat (Triticum aestivum) in the winters and soybean (Glycine max) in the summers, continuously, and represents the most common production system in the region; 2) Rotation I (Farmer crops rotation) - characterized by the inclusion of maize (Zea mays) each two years of soybean, and before of maize, black oats (Avena strigosa) is sown for soil cover, being this rotation used by farmers that already realize the importance of including other crops to seek more equilibrium in the production system, but it is still incipient as a diversified crops rotation; 3) Rotation II (Cash crops rotation) - consisted of cash crops as wheat and soybean, canola (Brassica napus) and maize, barley (Hordeum vulgare) and soybean, grown in the winter and summer, respectively, and was proposed to promote soil benefits through crops diversity without compromising the income return in the winter and summer; 4) Rotation III (Phytomass crops rotation) - consisted of consortium among black oats + rye (Secale cereale) + hairy vetch (Vicia villosa) in the winter, beans(Phaseolus vulgaris) in the summer and Sorghum (Sorghum bicolor) in summer/autumn, after black oats + hairy vetch + forage turnip (Raphanus sativus) in the winter, maize in the summer, and last year, triticale (Triticosecale rimpaui) + black oats + rye in the winter and soybean in the summer, and was proposed to intensify biomass production to increase organic matter and improving soil attributes (chemical, physical and biological), besides of nitrogen input provided by Fabaceae and longer soil protection by the high yield of Poaceae phytomass; 5) Rotation IV (cash and phytomass crops rotation) - consisted of a consortium between blue lupine (Lupinus angustifolius) + black oats for soil cover and nitrogen fixation, aiming to favor maize in the summer, after white oats (Avena sativa) in the winter followed by beans in the summer and forage turnip in summer/autumn, and last year, triticale in the winter and soybean in the summer; 6) Rotation $\mathrm{V}$ (consortium of Poaceae in the winter) - consisted of a black oat + ryegrass (Lolium multiflorum) in the winters, and soybean or maize, alternately, in the summers.

In order to evaluate the decomposition rate and half-life of winter crop residues, some species and consortia of species were selected from this experiment: 1 ) in 2014 were evaluated, wheat and, the consortia of black oats + hairy vetch + rye, black oats + ryegrass, and black oats + blue lupine; 2) in 2015 the crops evaluated were canola, black oats, and the consortium of black oats + hairy vetch + turnip; 3) in 2016 were barley, triticale and the triticale + black oat + rye consortium .

Table 1. Treatments composed by one crops succession and five crop rotations, under no-till system, in a three-year cycle, IAPAR, Ponta Grossa, Paraná State, Brazil

\begin{tabular}{|c|c|c|c|c|c|c|}
\hline \multirow[t]{2}{*}{ Treatments* } & \multicolumn{2}{|c|}{ Season $2014 / 15$} & \multicolumn{2}{|c|}{ Season $2015 / 16$} & \multicolumn{2}{|c|}{ Season $2016 / 17$} \\
\hline & Winter & Summer & Winter & Summer & Winter & Summer \\
\hline Succession & Wheat & Soybean & Wheat & Soybean & Wheat & Soybean \\
\hline Rotation I & Wheat & Soybean & Black oats & Maize & Wheat & Soybean \\
\hline Rotation II & Wheat & Soybean & Canola & Maize & Barley & Soybean \\
\hline Rotation III & $\begin{array}{c}\text { Black oats + Rye } \\
+ \text { Vetch }\end{array}$ & $\begin{array}{l}\text { Bean/ } \\
\text { Sorghum }\end{array}$ & $\begin{array}{c}\text { Black oats+ } \\
\text { Vetch } \\
+ \text { Turnip }\end{array}$ & Maize & $\begin{array}{c}\text { Black oats+ } \\
\text { Triticale+ } \\
\text { Rye }\end{array}$ & Soybean \\
\hline Rotation IV & $\begin{array}{c}\text { Blue lupine + } \\
\text { Black oats }\end{array}$ & Maize & White oats & $\begin{array}{l}\text { Bean/ } \\
\text { Turnip }\end{array}$ & Triticale & Soybean \\
\hline Rotation V & $\begin{array}{l}\text { Black oats } \\
+ \text { Ryegrass }\end{array}$ & Soybean & $\begin{array}{l}\text { Black oats } \\
+ \text { Ryegrass }\end{array}$ & Maize & $\begin{array}{l}\text { Black oats } \\
+ \text { Ryegrass }\end{array}$ & Soybean \\
\hline
\end{tabular}

Succession = crops succession, Rotation I = farmer crops rotation, Rotation II = cash crops rotation, Rotation III = phytomass crops rotation, Rotation IV = cash and phytomass crops rotation and Rotation V = winter Poaceae consortium. 
Crop management (planting season, sowing density, fertilization, and the pests, diseases and weed control) was performed according to the technical recommendations for each crop. The cover crops were no fertilized and none phytosanitary treatment or weed control were done. The winter cover crops were sown between April and May, and the winter crash crops between May and June.

For the determination of the dry phytomass produced by the species, three random sub-samples were collected with the aid of a $0.5 \times 0.5 \mathrm{~m}\left(0.25 \mathrm{~m}^{2}\right)$ wooden template, in the stage of full flowering for cover crops and cash crops, between September and October. The materials were dried in a forced air circulation oven at temperature of $60^{\circ} \mathrm{C}$ until constant weight, then weighed to obtain the dry phytomass, and reserved for preparation of the Litter bags (LBs).

The decomposition of crop residues was evaluated by the litter bag (LB) method [19]. The LBs were made of $1 \mathrm{~mm}$ mesh nylon, measuring $20 \times 20 \mathrm{~cm}$. In each plot were allocated, below the straw and in contact with the soil, LBs containing the corresponding crop residues, with previously known mass, after the sowing of summer cash crops, between October and November, depending on the crop sown.

Litter Bags were collected in seven times: 10 (T1), 25 (T2), 45 (T3), 70 (T4), 100 (T5), 130 (T6) and 160 (T7) days after placement in each plot, collecting one LB per plot at each time. After collected, the LBs were carefully cleaned to remove any soil excess that could be adhered to, and were placed in identified packages and brought to dry in a forced air circulation oven at $60^{\circ} \mathrm{C}$ for a period corresponding to 72 hours, then weighed to obtain the remaining dry phytomass in each time of decomposition.

The half-life of crop residues, which represents the time required for $50 \%$ of residual phytomass, after crop management or harvesting, to be decomposed, was calculated through the Equation 1 [20]:

$$
\mathrm{T}_{1 / 2}=(\ln 2) / \mathrm{k}
$$

Where: $\mathrm{T}_{1 / 2}=$ half-life time; $(\ln 2)=$ neperian logarithm of 2 , which is equivalent to $0.693 ; \mathrm{k}=$ decomposition constant that determines the rate of daily mass loss by plant residues.

The decomposition constant $(k)$ was obtained through the simple exponential equation $\left(Q=Q_{0} \exp ^{(-k t)}\right)$ generated by the decomposition curve [21].

Data of the produced, decomposed and remaining phytomass of the winter species were submitted to analysis of variance (ANOVA), applying the $F$ test to verify the differences between treatments, using the AgroEstat statistical program [22]. In significant cases, means were compared by Tukey test at $5 \%$ probability of error $(p<0.05)$. Species decomposition is represented by the exponential regression equations generated by the decomposition curves.

\section{RESULTS AND DISCUSSION}

The average biomass produced, decomposed and remaining, as well as the daily decomposition rate and half-life of the species and consortia are shown in Table 2. There was significant difference among the cover crops evaluated in the three years.

In winter 2014, Poaceae differed from other treatments because of their high phytomass production, with wheat producing an average of $10477 \mathrm{~kg} \mathrm{ha}^{-1}$ and oat + ryegrass consortium an average of $9651 \mathrm{~kg} \mathrm{ha}^{-1}$, without difference between them (Table 2). On the other hand, in the consortia in which the Fabaceae were inserted there was lower production of phytomass, also not differing from each other. In similar study, evaluating the production of different cover crops, was reported the highest biomass yields for single cultivated Poaceae compared to those intercropped with other species, reaching an average phytomass production of $10231 \mathrm{~kg} \mathrm{ha}^{-1}$ for the sorghum, yield close to that obtained for wheat in the present study [23]. The better performance of Poaceae as cover crops in NTS is mainly related to their fast initial development when compared to Fabaceae [24].

Against to what was observed for Poaceae in winter 2014, black oats in 2015 did not have the highest phytomass production among the evaluated coverings. This year, canola (Brassicacea) obtained the highest average of dry phytomass, with $10611 \mathrm{~kg} \mathrm{ha}^{-1}$ (Table 2). The canola has a more developed root system, characteristic that favors this crop during drought periods, besides to have a fast initial development and reaching a great height [25], which favors its high production of phytomass. Single black oats and the black oats + hairy vetch + turnip consortium did not differ, with mean dry mass values of 4329 and $4383 \mathrm{~kg} \mathrm{ha}^{-1}$, respectively (Table 2 ). Similar amount of dry phytomass for black oats was observed in a similar study with an average of $4879 \mathrm{~kg} \mathrm{ha}^{-1}$ [26].

In 2016, triticale presented the highest dry mass production, with $11384 \mathrm{~kg} \mathrm{ha}^{-1}$, followed by the Poaceae consortium (triticale + black oats + rye), with $10813 \mathrm{~kg} \mathrm{ha}^{-1}$ of dry mass (Table 2). In another study, triticale 
obtained $9328 \mathrm{~kg} \mathrm{ha}^{-1}$ of dry mass produced [27]. Barley presented the lowest production of phytomass, differing from the other Poaceae evaluated.

Table 2. Dry phytomass produced, decomposed and remaining after 160 days, daily decay rate and half-life of winter species in 2014, 2015 and 2016

\begin{tabular}{|c|c|c|c|c|c|c|}
\hline \multirow[t]{3}{*}{ Crop residues } & \multicolumn{3}{|l|}{ Phytomass } & \multicolumn{2}{|c|}{ Decomposition rate } & \multirow{2}{*}{$\begin{array}{c}\text { Half-life } \\
\text { time }\end{array}$} \\
\hline & Produced & Decomposed & Remaining & & & \\
\hline & \multicolumn{3}{|c|}{$\mathrm{kg} \mathrm{ha}^{-1}$} & $\mathrm{Kg} \mathrm{ha}^{-1} \mathrm{dia}^{-1}$ & $\% \mathrm{dia}^{-1 *}$ & Days \\
\hline \multicolumn{7}{|l|}{ Winter 2014} \\
\hline Wheat & 10477 a & 6705 a & 3772 a & 42 & $0,40^{( \pm 0.04)}$ & 116 \\
\hline Black oats + Ryegrass & 9651 a & 5694 a & $3957 \mathrm{a}$ & 36 & $0,37^{( \pm 0.05)}$ & 139 \\
\hline B. oats + Blue lupine & $7133 b$ & $5136 \mathrm{ab}$ & $1997 \mathrm{~b}$ & 32 & $0,45^{( \pm 0.07)}$ & 69 \\
\hline B. Oats + Rye + Vetch & $5850 \mathrm{~b}$ & 4621 a & $1228 \mathrm{~b}$ & 29 & $0,49^{( \pm 0.05)}$ & 87 \\
\hline CV (\%) & 11.46 & 30.12 & 26.50 & & & \\
\hline \multicolumn{7}{|l|}{ Winter 2015} \\
\hline Canola & 10611 a & 6368 a & 4243 a & 40 & $0,38^{( \pm 0.03)}$ & 139 \\
\hline Black oats & $4329 \mathrm{~b}$ & $2720 b$ & $1609 \mathrm{~b}$ & 17 & $0,39( \pm 0.01)$ & 139 \\
\hline B. oats+ Vetch+ Turnip & $4383 \mathrm{~b}$ & $2774 \quad b$ & $1609 \mathrm{~b}$ & 17 & $0,40^{( \pm 0.02)}$ & 139 \\
\hline CV (\%) & 16.27 & 13.45 & 28.61 & & & \\
\hline \multicolumn{7}{|l|}{ Winter 2016} \\
\hline Barley & $7470 \mathrm{~b}$ & $6297 \mathrm{~b}$ & $1173 \mathrm{~b}$ & 39 & $0,53^{( \pm 0.01)}$ & 58 \\
\hline Triticale & 11384 a & 8926 a & 2458 a & 56 & $0,49( \pm 0.01)$ & 87 \\
\hline Triticale+ B. Oats+ Rye & $10813 a b$ & $7907 \mathrm{ab}$ & 2906 a & 49 & $0,46^{( \pm 0.02)}$ & 87 \\
\hline CV (\%) & 15.64 & 20.72 & 21.58 & & & \\
\hline
\end{tabular}

Means followed by the same letter do not differ from each other by the Tukey test at $5 \%$ probability of error. $\mathrm{CV}=$ coefficient of variation. * Standard deviation of the mean $( \pm)$.

In 2014, the consortia including Fabaceae, black oats + blue lupine and black oats + rye + hairy vetch presented daily decay rate of 0.45 and $0.49 \%$ day $^{-1}$, respectively (Table 2 ), being higher than those observed for Poaceae, single wheat $(0.40 \%)$ and the consortium between black oats and ryegrass $(0.37 \%)$. Fabaceae and Poaceae consortia presented shorter half-life time $\left(T_{1 / 2}\right)$, being 87 days for black oats + hairy vetch + rye and 69 days for blue lupine + black oats, when compared to 116 and 139 days for wheat and black oats + ryegrass, respectively (Table 2). This result is due to insertion of a Fabacea in the consortium, producing crop residues with intermediate $\mathrm{C} / \mathrm{N}$ ratio, leading to a faster decomposition when compared to the exclusive cultivation of Poaceae. In the present study, the Fabaceae and Poaceae consortia resulting in intermediate half-life time due to the equilibrium promoted by the consortium of species with low and high $\mathrm{C} / \mathrm{N}$ ratio, which leads to slower and gradual decomposition in relation to Fabaceae in exclusive cultivation.

In evaluations of single crops of Fabaceae and Poaceae, the treatments with Poaceae differed from the other species, presenting half-life of 130 days on average and Fabaceae less than 100 days [28]. The authors stands out the importance of the climate conditions for decomposition, once limited conditions of wet and temperature influences the action of the soil microbiota, reducing the speed of chemical reactions that occur for the crop residues decomposition.

Daily decomposition in 2015 was $0.38 \%$ day $^{-1}$ for canola, $0.39 \%$ for black oats and $0,40 \%$ day $^{-1}$ for black oats + hairy vetch+ turnip, presenting a total mass loss from 60,63 e $62 \%$ of the initial mass at 160 days from onset of decay (Table 2). However, it is important to stands out the fast decomposition over the early ten days, where the loss of dry mass was 25, 29 e $20 \%$ from the total dry mass produced, that is corresponding to 42,45 and $33 \%$ from the total dry mass lost at 160 days. The higher decomposition rate in the season 2015/16 may have been due to the influence of the higher concentration of rainfall in this period $(2161 \mathrm{~mm})$ compared to previous $(1757 \mathrm{~mm})$ and last $(1521 \mathrm{~mm})$ season evaluated (Figure 1). From these, 
1152, 1303 e $888 \mathrm{~mm}$ occurred during the decomposition period, from October to April, for 2014/15, 2015/16 e 2016/17 season, respectively, and there was a rainfall concentration in the beginning of the decomposition process, $487 \mathrm{~mm}$ at September-November/2015. The decomposition rate of canola in 2015 was $39.8 \mathrm{~kg}$ ha${ }^{1}$ day $^{-1}$, leaving after 160 days, $4243 \mathrm{~kg} \mathrm{ha}^{-1}(40 \%)$ of the initial dry biomass (Table 2 ), which was higher than other treatments in this season. Black oats and the consortium of black oats + hairy vetch + turnip showed similar behavior with average daily decomposition of $17 \mathrm{~kg} \mathrm{ha}^{-1}$ day $^{-1}$ (Table 2), remaining after 160 days only $1609 \mathrm{~kg} \mathrm{ha}^{-1}$ of dry phytomass for both.

The half-life of winter crop residues in 2015 was 139 days for canola, black oats + hairy vetch + turnip and black oats (Table 2). Poaceae have a higher $\mathrm{C} / \mathrm{N}$ ratio than Fabaceae and Brassicaceae, which reduces their daily decomposition rate [29]. This favors its cultivation when the objective is to keep the soil covered for longer periods of time. Corroborating, in other studies was obtained half-life of 141 days for black oats [30], 133 and 128 days for black oats residues decomposing during corn and soybean development, respectively [31]. In the present study, black oats decomposition was also evaluated during the corn development.

Daily decomposition rate in 2016 was $0.53,0.49$ and $0.46 \%$ day $^{-1}$ for barley, triticale and Poaceae consortium, respectively (Table 2). For barley, there was a higher decomposition intensity when compared to single triticale and Poaceae consortium, since from the total of $7470 \mathrm{~kg} \mathrm{ha}^{-1}$ produced phytomass, 6297 $\mathrm{kg} \mathrm{ha}^{-1}$ were decomposed, leaving only $1173 \mathrm{~kg} \mathrm{ha}^{-1}$ on the soil surface 160 days after the barley harvest. Even being all Poaceae species in 2016, there were differences in the decomposition dynamics. In a study comparing Poaceae, was found differences, reporting 131, 103 and 52 days for half-life time of millet, sorghum and brachiaria residues, respectively [31]. Regarding to the daily mass loss, a distinct behavior was observed for triticale and the consortium triticale + black oats + rye, presenting average daily decomposition of 56 and $49 \mathrm{~kg} \mathrm{ha}^{-1}$ day $^{-1}$, respectively. This shows that the insertion of other Poaceae in the consortium reduced the daily decomposition speed, which is also related to the amount of dry mass produced by these covers, since the production of phytomass of the triticale in single cultivation was higher.

The half-life time of the winter crop residues in 2016 presented the following sequence in days: triticale + oats + rye $(87)=$ triticale $(87)>$ barley (58) (Table 2). The half-life of crop residues is an important factor for choosing the appropriate species to be inserted in crop rotation systems under No-till.

The decomposition curves obtained for Poaceae, single wheat and the black oat + ryegrass consortium, from October/14 to April/15, show slow decomposition rate expressed by a slight curve due to the high $\mathrm{C} / \mathrm{N}$ ratio, characteristic of Poaceae (Figure 2). In addition, these species have a high capacity of phytomass production, providing protection to the soil with its crop residues for a longer period. Besides of the higher production of phytomass, Poaceae presents more lignin in its composition [15], which makes decomposition difficult, reducing its speed.

The decomposition curves of the treatments composed by the consortia between Fabaceae and Poaceae (Figures 2 ) were slightly more pronounced, especially after 30 days of decomposition onset. The accelerated decomposition may be due to the presence of a larger amount of $\mathrm{N}$, resulting from the biological fixation of $\mathrm{N}$ by the Fabaceae [32], which increases the soil microbiota activity [33]. Nitrogen is a necessary element for the metabolism of decomposer microorganisms, promoting greater activity of soil biota, and, consequently, accelerating decomposition when compared to Poaceae exclusive residues. The importance of Poaceae and Fabaceae consortium or its alternated cultivation in crop rotation systems can be highlights as a good practice, since the overlapping of crop residues with high and low $\mathrm{C} / \mathrm{N}$ ratio leads to a more equilibrated decomposition dynamics, providing good soil cover and, at the same time, nutrient cycling in line with nutrient demand by the crops following. 


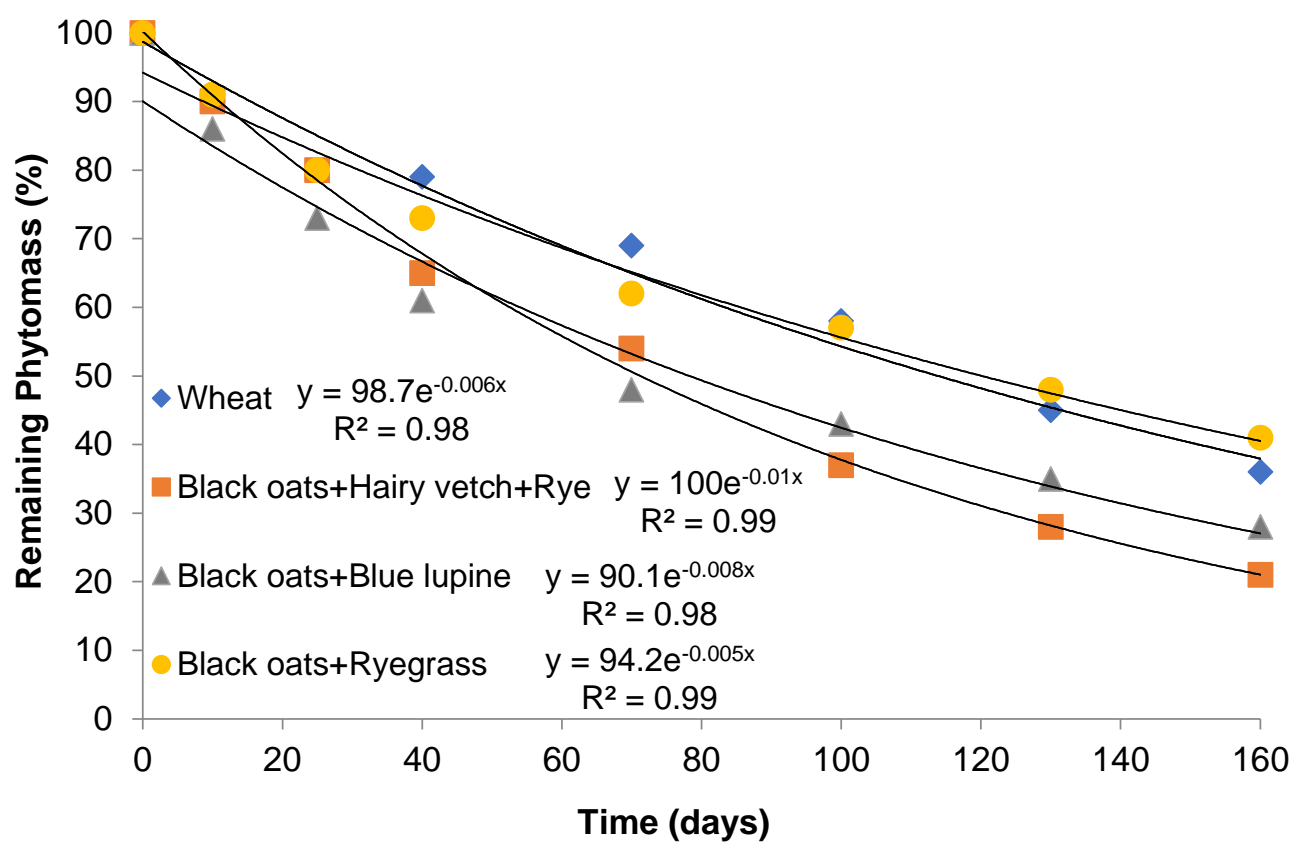

Figure 2. Decomposition curve of crop residues of winter species, single and in consortia: wheat, black oats + hairy vetch + rye, blue lupine + black oats, black oats + ryegrass, evaluated from Oct/2014 to Apr/2015, IAPAR, Ponta Grossa, State of Parana, Brazil.

The decomposition of cover crop residues, from October/15 to April/16, presented an initial phase with a significant decline in losses followed by a slower phase. At 45 days after the decomposition onset, canola loos $38 \%$ of the initial dry phytomass, and at 160 days the loss was $60 \%$ (Figure 3 ). Black oats at 45 days had lost of $42 \%$ of the initial phytomass, while at 160 days the loss represented $63 \%$. Evaluations of the decomposition process in different soil coverings in Cerrado's region, Brazil (tropical region), showed loss of $43 \%$ of the initial black oats phytomass at 42 days of decomposition [31].

At the beginning of the decomposition process, the mass loss was slightly more pronounced due to the rapid biodegradation of more labile compounds such as polysaccharides and proteins by the decomposer microorganisms [33]. After this time, according to the authors, the decomposition follows more slowly on recalcitrant compounds, such as phenolic compounds, celluloses and hemicelluloses. As a result, there is a relative increase in lignin content in relation to proteins in the crop residues along the time, which became the decomposition process more difficult and slow, reducing the phytomass loss. Therefore, certain materials, especially those with a higher $\mathrm{C} / \mathrm{N}$ ratio, can remain for long periods on the soil surface, protecting it.

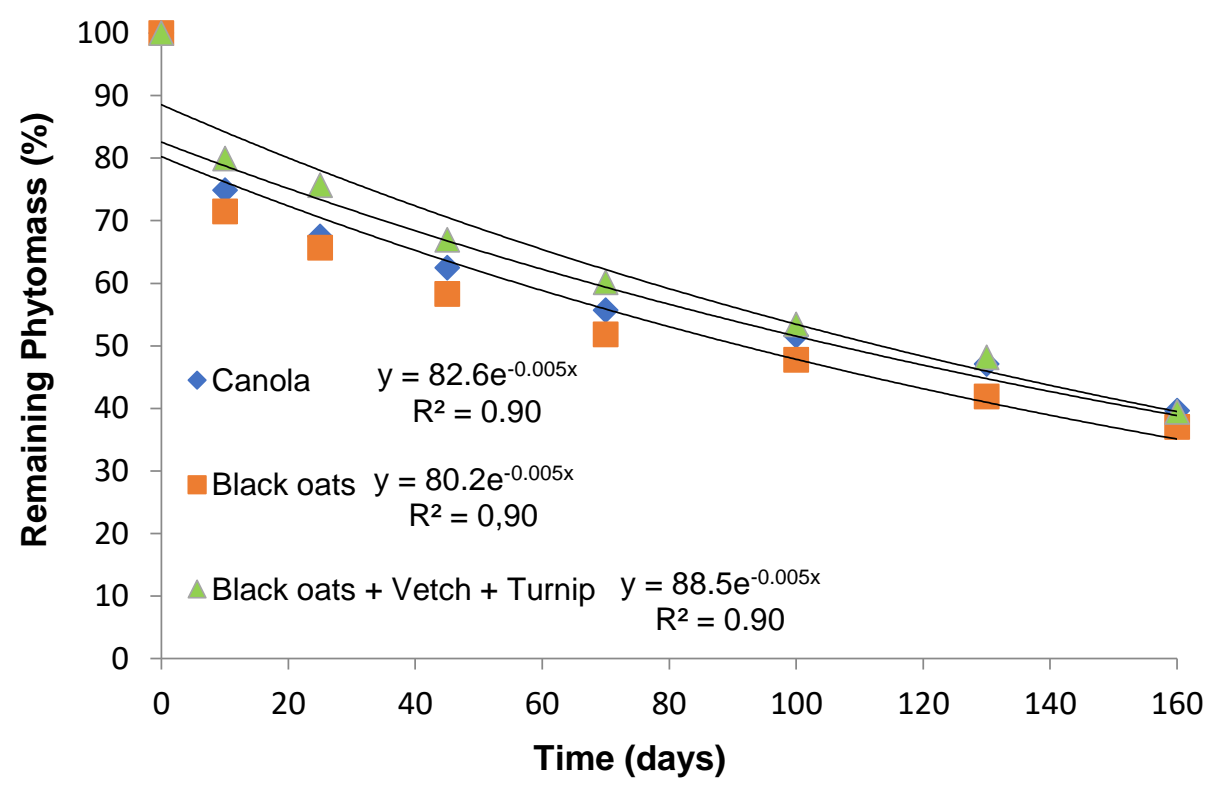

Figure 3. Decomposition curve of crop residues of winter species, single and in consortia: canola, black oats, black oats + hairy vetch + forage turnip, evaluated from Oct/2015 to Apr/2016, IAPAR, Ponta Grossa, Parana state, Brazil. 
The rapid initial decomposition of crop residues also may be related to weather conditions during the decomposition, since from Oct/15 to Dec/16, the rainfall was $649 \mathrm{~mm}$ (Figure 1b). Daily rainfall is the environmental factor that most affects the decomposition process [34], tending to accelerate the decomposition with greater precipitation.

In the season 2016/17, barley showed a slower decomposition than triticale in the first 30 days, but after this time there was a greater loss of mass, reaching a decomposition of $84 \%$ of its residues after 160 days, leaving only $16 \%$ of the initial phytomass on the soil surface (Figure 4 ). For triticale the loss was $46 \%$ of the phytomass at 45 days, and at 160 days the loss was $78 \%$. Both treatments presented a greater loss of mass initially, which decreased gradually along the time, due to the relative increase of the most recalcitrant compounds. The consortium of Poaceae presented behavior similar to triticale.

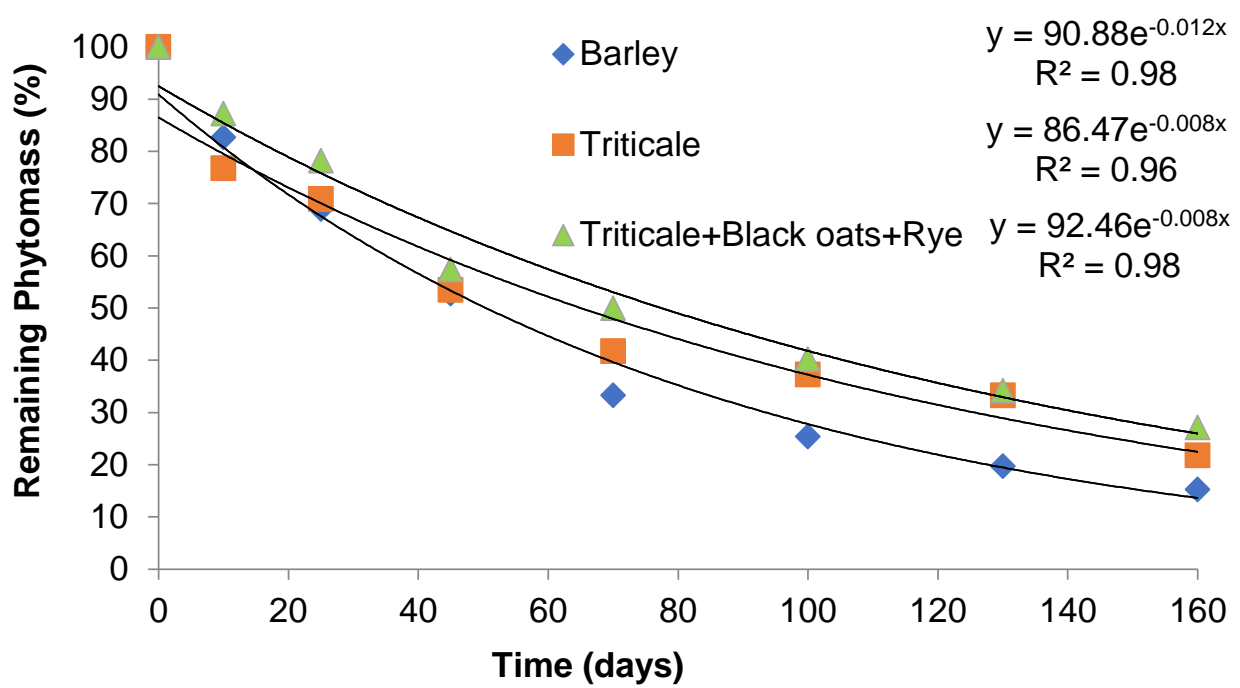

Figure 4. Decomposition curve of crop residues of winter, single species and consortium: barley, triticale, triticale + black oats + rye, evaluated from Oct/2016 to Apr/2017, IAPAR, Ponta Grossa, Paraná State, Brazil.

For subtropical region of the Brazil is recommended from 6 to $7 \mathrm{t} \mathrm{ha}^{-1} \mathrm{year}^{-1}$ of phytomass input for soil carbon accumulation and maintenance of the no-till system sustainability [35]. With exception of black oats and the consortium of black oats + vetch + turnip in 2015/16, all others winter crops and the consortia evaluating produced an amount of phytomass enough, compatible with the annual amount of crop residues recommended for the region, presenting slow and gradual decomposition and enabling its use in crop rotations under no-till system, in order to promote effective soil cover and nitrogen fixation (consortia with Fabacea), besides of promote soil carbon accumulation along the time. However, when added the summer crop residues to winter crop residues, all arrangements can produce enough annual amount of crop residues, generally more than recommended for the region, becoming the crop rotation systems sustainable.

\section{CONCLUSIONS}

Single Poacea, Poaceae consortia and canola presented higher phytomass production, with decomposition rate ranging from 0.37 to $0.53 \% \mathrm{dia}^{-1}$ when compared to Poaceae-Fabaceae consortia, with decomposition rate ranging from 0.40 to $0.49 \% \mathrm{dia}^{-1}$.

The half-life time for Poaceae-Fabaceae consortia was shorter than for single Poaceae, however, the use of Fabaceae-Poaceae consortium in the crops rotation can be a good strategy to produce phytomass and, in the same time, to diversity the production system.

\section{REFERENCES}

1. Lombardi Neto F, Dechen SCF, Conagin A, Bertoni J. Rotação de culturas: análise estatística de um experimento de longa duração em Campinas (SP) [Crops rotation: statiscal anlysis of a long-term experiment in Campinas (SP), Brazil]. Bragantia. 2002; 61(2):127-41.

2. Quirrenbach de Carvalho, I, da Silva MJS, Pissaia A, Pauletti V, Possamai JC. Espécies de cobertura de inverno e nitrogênio na cultura do milho em sistema de plantio direto [Species of winter cover crops and nitrogen to corn under no-tillage system]. Scientia. Agraria. 2007; 8(2):179-84. 
3. Franchini, JC, Costa JM, Debiasi H, Torres E. Importância da rotação de culturas para a produção agrícola sustentável no Paraná [Importance of crops rotation for sustainable agricultural production in Paraná]. LondrinaPR, Brazil: Embrapa; 2011. 52 p.

4. Gonçalves SL, Gaudencio, CA, Franchini, JC, Galerani, PR, Gracia A. Rotação de Culturas [Crops Rotation]. 45ª ed. Londrina-PR, Brazil: Embrapa; 2007. 10 p.

5. Doneda A, Aita C, Giacomini, SJ, Miola, ECC, Giacomini DA, Schirmann, J, Gonzatto, R. Fitomassa e decomposição de resíduos de plantas de cobertura puras e consorciadas [Phytomass and decompositionn of cover crops residues in monoculture and intercropping]. Rev. Bras Ciên. Solo. 2012; 36 (6):1714-23.

6. Calegari A. Plantas de cobertura e rotação de culturas em sistema plantio direto [Cover crops and crops rotation in no-tillage system]. In: Abdalla SRS, Prochnow LI, Fancelli AL. Simpósio discute como utilizar insumos e recursos para otimizar a produtividade do milho [Simposium discusses how to use inputs and resources to optimize corn productivity]. Piracicaba-SP, Brazil: IPNI, 2008. p. 1-32.

7. Barros DL, Gomide PHO, Carvalho GJ. Plantas de cobertura e seus efeitos na cultura em sucessão [Crover crops and their effects on sucessive crops]. Biosci. J. 2012; 29 (2):308-18.

8. Leite LFC, Freitas RCA, Sagrilo E, Galvão SRS. Decomposição e liberação de nutrientes de resíduos vegetais depositados sobre Latossolo Amarelo no Cerrado Maranhense [Decomposition and nutrients release from crop residues on a Yeallow Latosol in the savana, Manharão State, Brazil]. Rev. Cienc. Agron. 2010; 41(1):29-35.

9. Carvalho AM, Dantas RA, Coelho MC, Lima WM, Souza JPSP, Fonseca OP, Guimarães Júnior R. Teores de hemiceluloses, celulose e lignina em plantas de cobertura com potencial para sistema plantio direto no cerrado [Hemicellulosis, cellulose and lignin contents in cover crops with potential for no-tillage system in Cerrado, Brazil]. Planaltina-DF, Brazil: Embrapa; 2010.15 p.

10. Maluf HJGM, Soares EMB, da Silva IR, Neves JCL, Silva LOG. Decomposição de resíduos de culturas e mineralização de nutrientes em solo com diferentes texturas [Crop residues decomposition and nutrients mineralization in soils with different texture]. Rev. Bras Ciên. Solo. 2015; 39(6):1681-9.

11. Kliemann HJ, Braz AJPB, Silveira PM. Taxas de decomposição de resíduos de espécies de cobertura em Latossolo Vermelho distroférrico [Decomposition rate of cover crop species in a distroferrec Red Latosol. Pesq. Agropec.Trop. 2006; 1(36):21-8.

12. Ceretta CA, Basso CJ, Herbes MG, Poletto N, Silveira MJ. Produção e decomposição de fitomassa de plantas invernais de cobertura de solo e milho, sob diferentes manejos da adubação nitrogenada [Phytomass production and decomposition of winter cover crops and corn under different nitrogen fertilizations]. Cienc. Rural. 2002; 32(1):49-54.

13. Teixeira CM, de Carvalho GJ, de Andrade MJB, Silva CA; Pereira JM. Decomposição e liberação de nutrientes das palhadas de milheto e milheto + crotalária no plantio direto do feijoeiro [Cover crops residues decomposition and nutrients release from millet and millet + crotalaria under no-tillage of beans]. Acta Sci. Agron. 2009; 31(4):647653.

14. Zeich ARD, Conceição PC, Luchese AV, Balin NM, Candiotto G, Garmus TG. Proteção do solo por plantas de cobertura de ciclo hibernal na região Sul do Brasil [Soil protection by winter cover crops in Soth Brazil]. Pesq. Agropec. Bras. 2015; 50(5):374-82

15. Aita C, Giacomini SJ. Decomposição e liberação de nitrogênio de resíduos culturais de plantas de cobertura de solo solteiras e consorciadas [Residues decomposition and nitrogen release from single and intercropped soil cover plants]. R. Bras Ci. Solo. 2003; 27:601- 12.

16. Embrapa. Centro Nacional de Pesquisa de Solos (Rio de Janeiro, RJ). Sistema brasileiro de classificação de solos [Brazilian system of soil classification]. 2.ed. Rio de Janeiro-RJ, Brazil: Embrapa, 2006. 306 p. ISBN 85-85864-192.

17. Alvares CA, Stape JL, Sentelhas PC, Gonçalves JLM, Sparovek G. Köppen's climate classification map for Brazil. Meteorol. Z. 2013; 22, (6): 711-28.

18. IAPAR. Médias históricas em estações meteorológicas do IAPAR - Dados mensais Ponta Grossa [Metheorological Station of IAPAR (Ponta Grossa) - Historical average]. Available on line at http://www.iapar.br/ (accessed on: Fev.28, 2020).

19. Thomas RJ, Asakawa NM. Decomposition of leaf litter from tropical forage grasses and legumes. Soil Biol Biochem. 1993; 25:1351-1361.

20. Paul EA, Clark FE. Soil microbiology and biochemistry. San Diego, Academic Press, 1989. 275p.

21. Wieder RK, Lang GE. A critique of the analytical methods used in examining decomposition data obtained from litter bags. Ecology 1982, 63(6):1636-42. 
22. Barbosa JC, Maldonado Júnior W. AgroEstat - Sistema para Análises Estatísticas de ensaios agronômicos [System for statistical Analysis of agronomic trials]. Jaboticabal-SP, Brazil: Faculdade de Ciências Agrárias e Veterinárias Universidade Estadual Paulista, 2012.

23. Menezes LAS, Leandro WM, Oliveira Júnior JP, Ferreira ACB, Santana JG, Barros RG. Produção de fitomassa de diferentes espécies isoladas e consorciadas, com potencial de utilização para cobertura do solo [Phytomass production of different species, single and intercropped, with potential use for soil cover]. Biosci. J. 2009; 25(1):712.

24. Cazetta DA, Fornasieri Filho D, Girotto F. Composição, produção de matéria seca e cobertura do solo em cultivo exclusivo e consorciado de milheto e crotalária [Composition, dry matter production and soil cover in exclusive and intercropped cultivation of millet and crotalaria]. Acta Sci. Agron. 2005; 27:575-80.

25. Tomm GO. Canola: alternativa de renda e benefícios para os cultivos seguintes [Canola: alternative of income and benefits for the following crops]. Rev. Plantio Direto 2006; 15(94):4-8.

26. Soratto RP, Crusciol CAC. Produção de fitomassa e acúmulo de nutrientes pela aveia-preta em função da aplicação de calcário e gesso em superfície na implantação do sistema plantio direto [Black oat phytomass and nutrient accumulation as affected by surface application of lime and phosphogypsum during establishment of notillage system]. Cienc.Rural. 2008; 38(4):928-35.

27. Teixeira MCC, Rodrigues O, Nascimento Jr. A, Costenaro ER, Bozetti M. Ajuste de prática de manejo de plantas de centeio e triticale para a maximização do rendimento de grãos e forragem [Adjustment of rye and triticale plant management practices to maximize grain and forage yield]. Passo Fundo-RS, Brazil: EMBRAPA; 2008. 14p.

28. Torres JLR, Pereira MG, Fabian AJ. Produção de resíduo vegetal por plantas de cobertura e mineralização de seus resíduos em plantio direto [Cover crops biomass production and its residues mineralization in no-tillage system]. Pesq. Agropec. Bras. 2008; 43:421-8.

29. Alvarenga RC, Cruz JC, Viana JHM. Manejo de solos: Plantas de cobertura de solo [Soil management: Soil cover crops]. 4를 ed. Sete Lagoas-MG, Brazil: Embrapa, 2008. 6p.

30. Acosta JAA, Amado TJC, Silva LS, Santi A, Weber MA. Decomposição da fitomassa de plantas de cobertura e liberação de nitrogênio em função da quantidade de resíduos aportada ao solo sob sistema plantio direto [Phytomass decomposition and nitrogen release from cover crops as a function of the amount of residue added to the soil under no-tillage system]. Cienc. Rural. 2014; 44(5):801-9.

31. Torres JLR, Pereira MG, Fabian AJ. Decomposição e liberação de nitrogênio de resíduos culturais de plantas de cobertura em um solo de cerrado [Decomposition and nitrogen release from cover crop residues in a brazilian savana soil]. R. Bras Ci. Solo. 2005; 1(29):609-18.

32. Calegari, A, Tiecher T, Hargrove WL, Ralisch R, Tessier D, Tourdonnet S, Guimarães MF, Rheinheimer DS. Longterm effect of different soil management systems and winter crops on soil acidity and vertical distribution of nutrients in a Brazilian Oxisol. Soil Till Res. 2013; 133:32-9.

33. Balota EL, Calegri A, Nakatani AS, Coyne MS. et al. Benefits of winter cover crops and no-tillage for microbial parameters in a Brazilian Oxisol: A long-term study. Agr Ecosyst Environ. 2014; 197:31-40

34. Gonçalves SL, Saraiva OF, Torres E. Influência de fatores climáticos na decomposição de resíduos culturais de milho e soja [Influence of climatic factors on the decomposition of corn and soy crop residues]. Londrina-PR, Brazil: Embrapa; 2011. 26 p.

35. Amado TJ, Bayer C, Conceição PC, Spagnolo E, CAMPOS BHC, VEIGA M. Potential of $C$ accumulation in no-till soils with intensive use and cover crops in Brazil. J. Environ Qual. 2006; 35:1599-1607.

2020 by the authors. Submitted for possible open access publication under the terms and conditions of the Creative Commons Attribution (CC BY NC) license (https://creativecommons.org/licenses/by-nc/4.0/). 